\title{
Carbon monoxide emissions assessment by using satellite and modeling data: Central Mexico case study
}

\author{
Gilberto MALDONADO-PACHECO ${ }^{1}$, José Agustín GARCÍA-REYNOSO ${ }^{1 *}$, Wolfgang STREMME ${ }^{1}$, \\ Luis Gerardo RUIZ-SUÁREZ ${ }^{1}$, José Santos GARCÍA-YEE ${ }^{2}$, Cathy CLERBAUX ${ }^{3}$ and Pierre-François COHEUR ${ }^{4}$ \\ ${ }^{1}$ Centro de Ciencias de la Atmósfera, Universidad Nacional Autónoma de México, Circuito Exterior s/n, Ciudad \\ Universitaria, 04510 Ciudad de México, México. \\ ${ }^{2}$ Escuela Nacional de Ciencias Biológicas, Instituto Politécnico Nacional, Unidad Profesional Adolfo López Mateos, \\ Zacatenco, Av. Wilfrido Massieu 399, Col. Nueva Industrial Vallejo, 07738 Ciudad de México. México. \\ ${ }^{3}$ LATMOS/IPSL, Sorbonne Université, UVSQ, CNRS, Paris, France. \\ ${ }^{4}$ Atmospheric Spectroscopy, Service de Chimie Quantique et Photophysique, Université Libre de Bruxelles, Brussels, \\ Belgium.
}

*Corresponding author; email: agustin@atmosfera.unam.mx

Received: March 15, 2019; accepted: February 18, 2020

\begin{abstract}
RESUMEN
En este trabajo se cuantifican y reducen las diferencias de las emisiones en el inventario 2008 respecto a las reales mediante el uso de observaciones satelitales y modelación. Se hacen comparaciones de columna de monóxido de carbono de los datos satelitales del Interferómetro de Sondeo Atmosférico Infrarrojo (IASI, por sus siglas en inglés) contra columnas obtenidas del modelo WRF-Chem, durante febrero de 2011. El análisis se realiza a la hora local del paso satelital (10:00 a.m., aproximadamente) sobre la Ciudad de México. Se empleó el inventario nacional de emisiones 2008 generado por la Secretaría del Medio Ambiente y Recursos Naturales. Se utilizó un método de inversión con los datos de columna del modelo y observados; con ello se obtuvieron factores de escalamiento para cinco regiones y la concentración proveniente de las fronteras del dominio del modelo, los cuales se emplearon para actualizar las emisiones. Estas emisiones actualizadas se usaron en la modelación y el resultado se comparó contra mediciones en superficie. Para la Ciudad de México y el Área Metropolitana se obtuvo un factor de escalamiento igual a 0.43 al emplear el Inventario Nacional de Emisiones 2008; para Toluca, Morelos y Puebla se estimó un factor menor a uno, mientras que para Hidalgo y la concentración proveniente de las fronteras del modelo fue cercano a dos. El desempeño del modelo mejoró al incrementar el índice de concordancia y disminuir el error cuadrático medio cuando se utilizaron las emisiones actualizadas de CO.
\end{abstract}

\begin{abstract}
This paper quantifies and reduces the differences in emissions from the 2008 inventory with respect to the real ones through the use of satellite observations and modeling. Carbon monoxide column comparisons from the Infrared Atmospheric Sounding Interferometer (IASI) satellite data were made against columns obtained from the WRF-Chem model, during February 2011. The analysis was carried out at the satellite passage local time (approximately 10:00 LT) over Mexico City. The 2008 National Emissions Inventory generated by the Mexican Ministry of Environment and Natural Resources was utilized. An inversion method was applied to the modeled and observed column data. With the above, scaling factors were obtained for five regions and the concentration from the model domain boundaries, which were used to update the emissions. These were used in modeling and the result was compared with surface measurements. For Mexico City and the Metropolitan Area, a scaling factor equal to 0.43 was obtained when using the 2008 emissions inventory; for Toluca, Morelos and Puebla, a less than one factor was estimated, while for Hidalgo and the concentration from model boundaries it was close to two. The model performance was improved by an increment in the agreement index and a reduction on the mean square error when the updated $\mathrm{CO}$ emissions were used.
\end{abstract}


Keywords: CO column, averaging kernel, scaling factor, IASI, WRF-chem.

\section{Introduction}

Carbon monoxide (CO) is a gas emitted mainly at the surface level by fossil fuels combustion and biomass burning (Kerzenmacher et al., 2012, Stremme et al., 2013). In the atmosphere it is produced and removed by hydrocarbons oxidation and chemical reaction with the hydroxyl radical $(\mathrm{OH})$, respectively. Due to its lifetime of weeks to a few months in the troposphere, depending on where it is analyzed and the season of the year, $\mathrm{CO}$ has been used as an atmospheric transport tracer (Rinsland et al., 2006; de Foy et al., 2007; Funke et al., 2007; Turquety et al., 2008, 2009; George et al., 2009; de Wachter et al., 2012).

$\mathrm{CO}$ is not only measured in surface but also at different altitudes employing remote sensing, such as satellite measurements from the Measurement of Pollution in the Troposphere (MOPITT), the Scanning Imaging Absorption Spectrometer for Atmospheric Chartography (SCIAMACHY), and the Infrared Atmospheric Sounding Interferometer (IASI), among other instruments (Luo et al., 2007; Clerbaux et al., 2008a; Turquety et al., 2008). These observations can also provide information of $\mathrm{CO}$ surface concentrations and its transport over polluted urban areas (Clerbaux et al., 2008b; Fortems-Cheiney et al., 2009; Fagbeja et al., 2015; Rakitin et al., 2015; Bauduin et al., 2016).

Several studies have been carried out around the world employing satellite observations, e.g., Liu et al. (2005) studied the MOPPIT detection of CO emission from large forest fires in the United States during 2000; Tanimoto et al. (2009) analyzed CO plumes transported from western Siberia toward northern Japan using images from the Atmospheric Infrared Sounder (AIRS); Kopacz et al. (2009) constrained Asian sources of CO by using an atmospheric chemical transport model (GEOS-Chem CTM) and observations from MOPITT; Klonecki et al. (2012) evaluated the IASI CO product against independent in-situ aircraft and analyzed the impact of eight months assimilation of IASI CO columns; Marey et al. (2015) presented a satellite-based analysis to explore contributing factors that affect tropospheric CO levels over Alberta, Canada, and Rakitin et al. (2017) estimated trends of total CO over Eurasia using information from AIRS.
Previous studies have been carried out in Mexico City and its surrounding metropolitan area, such as the conducted by de Foy et al. (2007), in which vertical column measurements of $\mathrm{CO}$, derived from Fourier Transform Infrared (FTIR) spectrometers, were used to constrain the $\mathrm{CO}$ emission in models, and the $\mathrm{CO}$ emission was also evaluated in the inventory for this region; Stremme et al. (2013) presented a new methodology for estimating $\mathrm{CO}$ emissions on large urban areas based on a top-down approach using FTIR measurements from ground and space (employing the IASI instrument), and Bauduin et al. (2016) investigated the capability of IASI to retrieve near-surface $\mathrm{CO}$ concentrations and evaluated the influence of thermal contrast. These works focused on analyzing $\mathrm{CO}$ emissions in Mexico City, but it is important to study other surrounding regions.

Regarding IASI, it is one of the most recent satellite instruments that measure $\mathrm{CO}$. It was launched in 2006 on board the Metop-A satellite. The field of view is $50 \mathrm{~km}$ with four circular measurements of $12 \mathrm{~km}$ at nadir and has a swath of $2200 \mathrm{~km}$ that allows to observe the planet twice a day (Clerbaux et al., 2009; Hilton et al., 2012). The satellite is sun-synchronous with equator crossing times of 09:30 and 21:30 LT (Clerbaux et al., 2009; Fortems-Cheiney et al., 2009; George et al., 2009; Turquety et al., 2009) and the crossing hour over central Mexico is approximately at 10:00 LT (Stremme et al., 2013). In addition, IASI has a resolution of $0.5 \mathrm{~cm}^{-1}$ in a spectral range from 645 to $2760 \mathrm{~cm}^{-1}$.

This work aims to reduce the differences between the observed and modeled carbon monoxide concentrations by employing the WRF-Chem model fed with the 2008 emissions inventory. To do this, a methodology was applied to compare WRF-Chem and IASI data, obtaining scaling factors that allow to update carbon monoxide emissions for a specific period.

\section{Methodology}

2.1 Model and data description

The WRF-Chem model (Grell et al., 2005; Fast et al., 2006) was used to estimate CO concentrations. The model was fed with NCAR one-degree resolution 
meteorological data and two nested domains were modeled using the USGS 24-category land-use: the first one with a 90 by 90 cells mesh grid with $9-\mathrm{km}$ resolution and the second with an 88 by 88 cells mesh grid with $3-\mathrm{km}$ resolution (Fig. 1). February 2011 was modeled because it was the month with more available surface measurement data (from a campaign carried out in the State of Mexico). The parameterizations employed in this work are the YSU scheme for the boundary layer (Song-You et al., 2006), the WRF Single-Moment 5-class scheme (WSM5) for microphysics (Song-You et al., 2004), Rapid Radiative Transfer Model scheme (RRTM) for the longwave radiation (Mlawer et al., 1997), the Goddard scheme for the shortwave radiation (Matsui et al., 2018) and the Grell-3 scheme for the cumulus option (Grell, 1993; Grell et al., 2002)

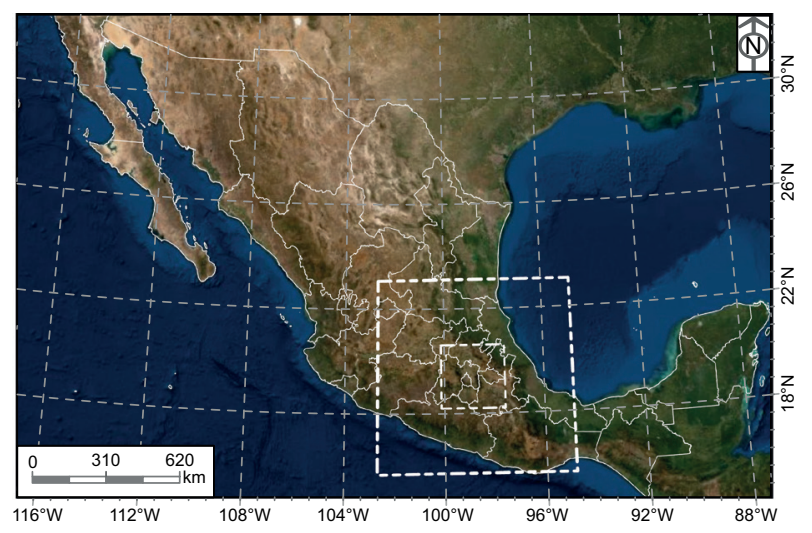

Fig. 1. Modeling domains (white squares). The largest domain has a $9-\mathrm{km}$ resolution and the smallest a $3-\mathrm{km}$ resolution.

The 2008 National Emissions Inventory (GarcíaReynoso et al., 2018) was used because at the time of the analysis only these emission data were available. The National Emissions Inventory was developed by the Mexican Ministry of Environment and Natural Resources (SEMARNAT). It includes information on emissions released into the atmosphere from criteria pollutants: carbon monoxide $(\mathrm{CO})$, nitrogen oxides $\left(\mathrm{NO}_{\mathrm{x}}\right)$, sulfur oxides $\left(\mathrm{SO}_{\mathrm{x}}\right)$ and particles with aerodynamic diameter less than 10 and $2.5 \mu \mathrm{m}\left(\mathrm{PM}_{10}\right.$ and $\mathrm{PM}_{2.5}$ ), volatile organic compounds (VOCs) and ammonium $\left(\mathrm{NH}_{3}\right)$, emitted from area, mobile and fixed sources. It is elaborated periodically and is available from the internet (https://www.gob.mx/ semarnat/documentos/documentos-del-inventario-nacional-de-emisiones). Its elaboration follows international standards, and it has some quality assurance procedures for the input, the processing and the reporting of information. The annual emissions inventory was processed in order to be suitable to use in the WRF-Chem model following the methodology presented by García-Reynoso et al. (2018).

Regarding the satellite data, we used the Fast Optimal Retrievals on Layers for IASI (FORLI-CO) (https://iasi.aeris-data.fr/CO_IASI_A_data/), which calculates the $\mathrm{CO}$ profile in 19 layers with a $1-\mathrm{km}$ thickness in the first 18 layers and up to a $60-\mathrm{km}$ altitude in the last one (Hurtmans et al., 2012; de Wachter et al., 2012). All the CO total column data were obtained at 10:00 LT, approximately (Stremme et al., 2013), including the averaging kernel matrix, its associated errors, and the a priori profile, among other values.

In order to compare the model results against surface observations, data from five stations of Mexico City's Automatic Air Quality Monitoring Network (RAMA, Spanish acronym) were used: Iztacalco (IZT), Merced (MER), Santa Úrsula (SUR), Tlalnepantla (TLA) and UAM Iztapalapa (UIZ). This monitoring network reports hourly concentrations of $\mathrm{CO}, \mathrm{SO}_{2}, \mathrm{O}_{2}$, and $\mathrm{NO}_{\mathrm{x}}$, among other chemical and meteorological variables. In addition, the United States Environmental Protection Agency (USEPA) has been performing audits to stations within Mexico City's air monitoring network since 2009, evaluating their systems for station operation and calibration (http://www.aire.cdmx.gob.mx/default. php?opc $=\% 27 \mathrm{ZaBhnmI}=\& \mathrm{dc}=\% 27 \mathrm{Zg}==)$.

Additionally, data from a surface measurement campaign in the State of Mexico were used in the Amecameca (AME), Tenango (TEN) and Ozumba (OZU) municipalities (Fig. 2).

\subsection{Modeling procedure}

Dedicated CO emission inventories were created for the $3-\mathrm{km}$ resolution model domain. These inventories only have $\mathrm{CO}$ emissions for some specific regions: The Mexico City Metropolitan Area (MCMA), the Toluca and Lerma municipalities, and Morelos, Puebla and Hidalgo states (Fig. 3). A zero-emission value was placed on the remaining domain areas and the concentration from model boundaries was considered. 


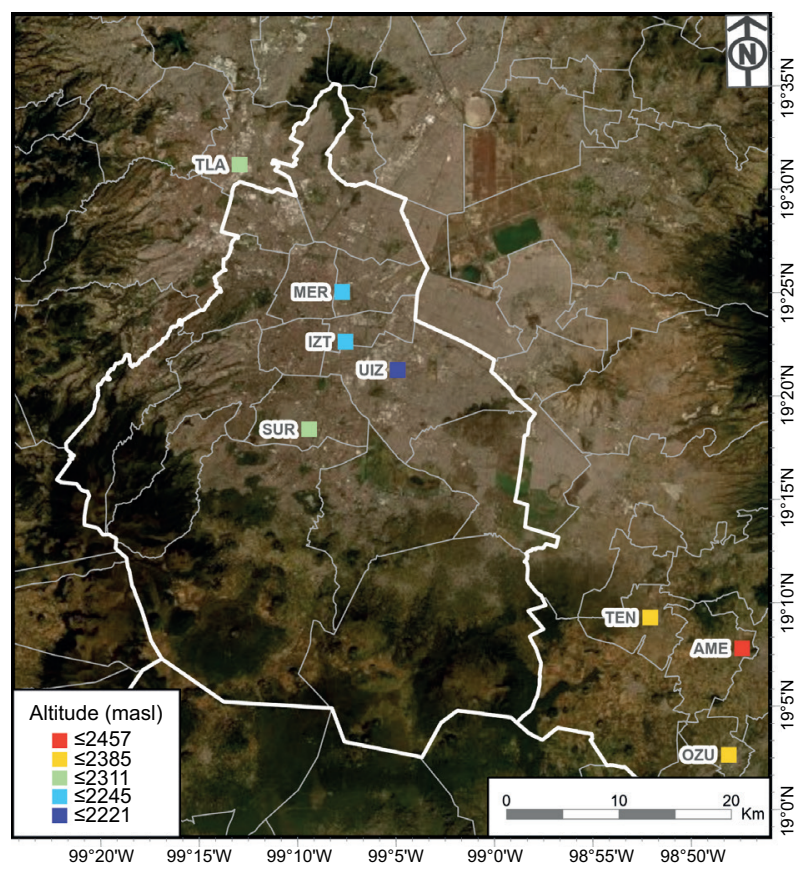

Fig. 2. Location of the measurement stations and their approximate altitude.

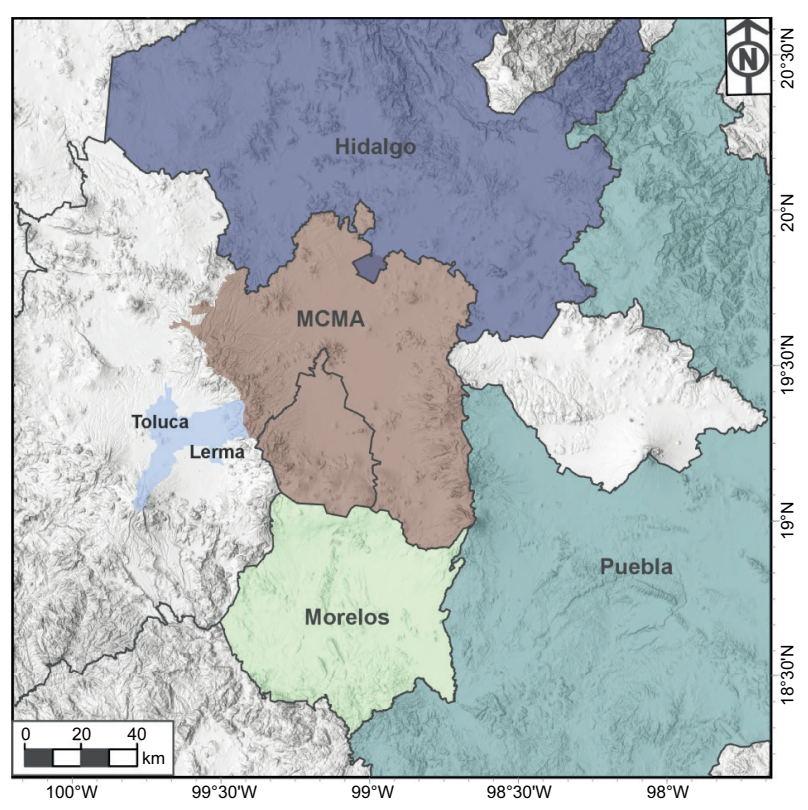

Fig. 3. Metropolitan areas that were used to evaluate the influence of surrounding cities over the MCMA.

Subsequently, the WRF-Chem model was run for February 1-28,2011. The chemistry was turned offin order to model five tracers (considering the concentration from model boundaries) with the purpose of knowing the influence of each region on the others.

\subsubsection{Model total column calculation procedure}

It is known that the satellite crossing time over central Mexico is around 10:00 LT (Clerbaux et al., 2009; Stremme et al., 2013). Therefore, the comparisons between satellite and modeled data are made at this time. For this, it is necessary to compute the $\mathrm{CO}$ modeled columns (in molecules per $\mathrm{cm}^{2}$ ) for each grid by using the concentration in every level (in parts per million in volume [ppm]), temperature, pressure and layer thickness (Lt).

First, the model height of each level and the thickness of each layer are obtained:

$$
\begin{aligned}
& Z=\frac{(P H+P H B)}{9.8} \\
& L_{t}=Z_{n+1}-Z_{n}
\end{aligned}
$$

where $L_{\mathrm{t}}$ is the layer thickness (m), $Z$ the level height in meters (m), $P H$ the geopotential height $\left(\mathrm{m}^{2} \mathrm{~s}^{-2}\right)$, and $P H B$ the geopotential perturbation $\left(\mathrm{m}^{2} \mathrm{~s}^{-2}\right)$.

Then, the state equation is used for the calculation of molecules $\mathrm{cm}^{-2}$ :

$\frac{\text { Molecules number }}{\mathrm{cm}^{2}}=\frac{C_{c o} * P^{*} N A^{*} L_{t}}{R^{*} T^{*} 10^{4}}$

where $P=P(\mathrm{~atm})=\frac{P_{\text {model }}+P B}{101325}$

$C_{\text {co }}$ is the $\mathrm{CO}$ concentration in $\mathrm{ppm}\left(\mathrm{mL} \mathrm{m}^{-3}\right)$, $R=82.57\left(\mathrm{~mL}\right.$ atm $\left.\mathrm{mol}^{-1} \mathrm{~K}^{-1}\right), N A$ is the Avogadro number (molecules $\mathrm{mol}^{-1}$ ), $P_{\text {model }}$ is the model pressure $(\mathrm{Pa}), P B$ is the pressure perturbation $(\mathrm{Pa})$, and $T$ :

$T(K)=\left(T_{\text {model }}+300\right) *\left(\frac{P}{P_{0}}\right)^{0.284}$

where $T_{\text {model }}$ is the perturbation potential temperature $\left(\theta-T_{0}\right)(\mathrm{K}),\left(T_{0}=300\right)$, and $P_{0}$ the reference pressure (1 atm).

Then, this method allows to estimate the modeled partial columns for each layer in the model.

\subsubsection{Scaling factors calculation procedure}

According to Rodgers and Connor (2003), in order to compare total columns from different instruments 
that have different characteristics and vertical sensitivity, it is necessary to perform a data treatment that includes some of their characteristics. In this case, IASI's averaging kernels were used, which provide information about the vertical sensitivity of the retrieval to the true state of the atmosphere (Eq. [6a]) (Rodgers, 2000; Luo et al., 2007).

$\left(x_{\text {sat }}-x_{a}\right)=\operatorname{Asat}\left(x_{\text {true }}-x_{a}\right)+\varepsilon$

where $x_{\text {sat }}$ is the retrieved profile, $x_{a}$ the IASI a priori profile, Asat the IASI's averaging kernels, $x_{\text {true }}$ the true but unknown profile, and $\varepsilon$ the error in the retrieved profile.

For the comparison, we assume that the modeled profile is the true profile.

Therefore, the satellite averaging kernels were first interpolated to the model heights in each coincident point. Next, the modeled $\mathrm{CO}$ profiles were smoothed by using Eq. (6b):

$x_{\text {model_smoothed }}=A \cdot x_{\text {model }}+(1-A) \cdot x_{a}$

where $x_{\text {model smoothed }}$ is the smoothed model profile, $A$ the averaging kernel interpolated to model heights, and $x_{\text {model }}$ the original model profile.

In this work we used the satellite total column. Then, the total column operator was applied for modeled partial columns $(\mathrm{g}=[111111 \ldots .1])$ to sum up all modeled partial columns:

$g x_{\text {model_smoothed }}=g A \cdot x_{\text {model }}+(g-g A) \cdot x_{a}$

Afterwards, a matrix $K$ was created. Its columns correspond to the smoothed total column values calculated by Eq. (6c) for each region and the concentration from model boundaries. Its rows indicate the number of coincident points between the satellite and the model. Therefore, in this specific work: K $(1074,6)$.

The modeled $\mathrm{CO}$ total column of each grid point and time is a linear combination of different origin $\mathrm{CO}$ molecules sum, which is represented by Eq. (6d):

$$
\begin{aligned}
& x_{\text {model }}=x[1] x_{\text {Toluca }}+x[2] x_{\text {Mexico City }}+\ldots+x[6] x_{\text {Boundary }} \\
& g x_{\text {model_smoothed }}-(g-g A) \cdot x_{a}= \\
& g A x[1] x_{\text {Toluca }}+g A x[2] x_{\text {Mexico City }}
\end{aligned}
$$

After that, we calculated the scaling factors using Eq. (7):

$y^{\prime}=K x$

where:

$y^{\prime}=y-g($ Asat -1$) x_{a}$

and $x$ is the scaling vector; $K$ the matrix that contains the smoothed total columns for each region and the concentration from model boundaries for every coincident point, and $y$ the vector that contains the total satellite columns in the coincident points.

Solving equation 7 for $\mathrm{x}$ :

$x=G \cdot y^{\prime}$

where

$G=\left(K^{T} \cdot K\right)^{-1} \cdot K^{T}$

Subsequently, the emissions were scaled by multiplying the original emissions from each region by its corresponding scaling factor, not only at 10:00 LT but at all times. Afterwards, the model was run using the scaled emission inventories and chemistry turned on. Finally, these model results were compared against surface measurements at 10:00 LT, time at which the total column analysis was made.

\section{Results}

Having performed the procedure described in the methodology section, Table I presents the scaling

Table I. Scaling factors for February 2011, estimated with respect to the 2008 emissions inventory.

\begin{tabular}{lcc}
\hline Region & Scaling factor & Uncertainty (\%) \\
\hline Mexico City and & & \\
Metropolitan Area & 0.43 & 5.62 \\
Toluca & 0.30 & 16.28 \\
Morelos & 0.44 & 21.12 \\
Puebla & 0.72 & 12.98 \\
Hidalgo & 2.00 & 45.16 \\
Boundary & 1.86 & 0.40 \\
\hline
\end{tabular}


factors and their associated uncertainties estimated for each region after comparing modeled and satellite total columns.

For the MCMA it is observed that the scaling factor is 0.43 , while for Toluca, Morelos and Puebla it is also less than 1 . This means that it is necessary to reduce the contribution from these regions to the $\mathrm{CO}$ total column; therefore, $\mathrm{CO}$ emissions must be reduced with respect to the original run. In the case of Hidalgo and the boundary concentration, the scaling factors are greater than 1 , so their contribution to the total column must increase; consequently, $\mathrm{CO}$ emissions must increase.

Regarding uncertainties, the smallest are estimated for the MCMA and the background concentration, and the greatest are calculated for Morelos and Hidalgo. This might be related to lower emissions in these areas.

The method considers each region emissions and uses the coincident points to reduce the differences between satellite and modeled data. Because the analysis is done by region and not by coincident point, it is possible to estimate a single scaling factor for each region and consequently the differences between the model data and satellite observations are reduced.

\subsection{Comparisons between measured data and mo- del results}

After applying the scaling factors, the model was run with chemistry turned on. Comparisons between model results and surface measurements were made in the modeled period at 10:00 LT. The stations are located in Mexico City and its surroundings, and this analysis can help us to obtain information about the model performance at this hour.

Figure 4 shows box plots for the RAMA stations (Fig. 2) and the model results using original and scaled emissions at 10:00 LT, which is approximately the satellite crossing hour over central Mexico. In general, the model predicts higher concentrations than the measurements when original emissions are used; however, when inventories are scaled, model results are closer to the observations, indicating an improvement in the model performance at this time.

Figure 5 shows box plots for the modeled concentrations against measurement data obtained from a campaign made in three locations in the State of Mexico: Amecameca, Ozumba and Tenango (Fig. 2),

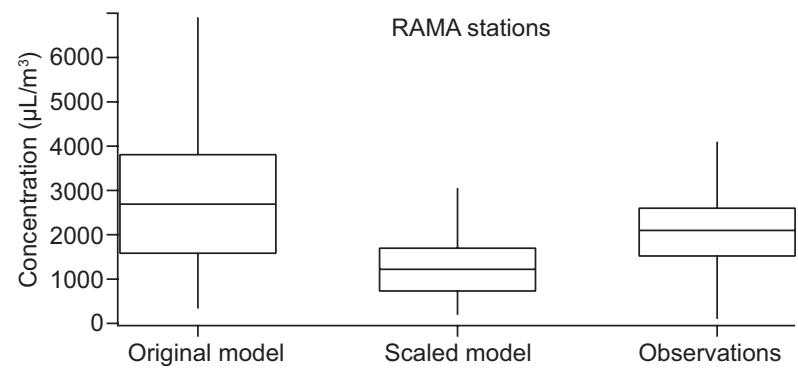

Fig. 4. Comparison between model and surface observations for RAMA stations $\left(\mu \mathrm{L} / \mathrm{m}^{3}\right)$.

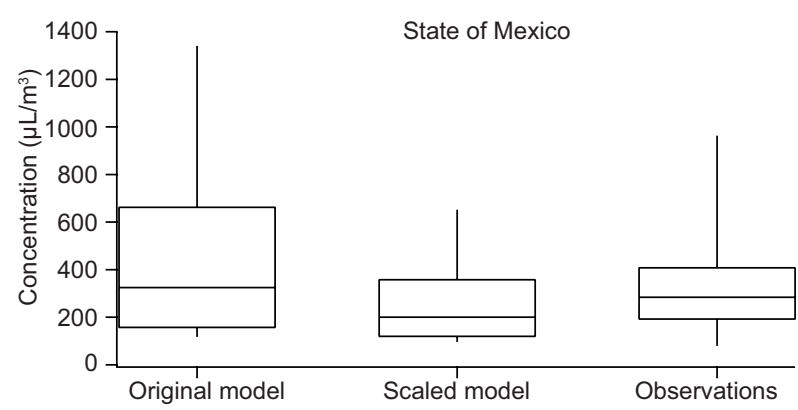

Fig. 5. Comparison between model and surface observations for stations in the State of Mexico $\left(\mu \mathrm{L} / \mathrm{m}^{3}\right)$.

from February 6 to March 8, 2011. In the image, the analysis was carried out in the corresponding period February 6-28, 2011. Again, two modeling cases are presented, using original and scaled emissions at 10:00 LT.

It is observed that the model results are higher than the measurements when the original emissions are used; however, an improvement in the model performance is found when the scaled emissions are employed.

\subsection{Ratios comparison for modeled and observed data}

Another method to evaluate inventory emissions outside of Mexico City is to compare observed modeled ratios obtained from surface and total column. This was made for the State of Mexico stations because more information, related to meteorological conditions, is available.

García-Yee et al. (2017) observed, from the State of Mexico campaign, that under low pressure synoptic systems (LPS) southerly winds (from Morelos and Puebla) predominated throughout most of the 
Table II. Ratio comparison: satellite model versus observations model (surface).

\begin{tabular}{|c|c|c|c|c|c|c|}
\hline \multirow[b]{2}{*}{ Station } & \multicolumn{2}{|c|}{ Molecules $/ \mathrm{cm}^{2}$} & \multicolumn{2}{|c|}{$\mu \mathrm{L} / \mathrm{m}^{3}$} & \multicolumn{2}{|c|}{ Ratio } \\
\hline & Satellite & Model & $\begin{array}{c}\text { Surface } \\
\text { observations }\end{array}$ & $\begin{array}{c}\text { Model } \\
\text { (surface) }\end{array}$ & $\begin{array}{c}\text { Satellite/ } \\
\text { model }\end{array}$ & $\begin{array}{c}\text { Observations/ } \\
\text { model }\end{array}$ \\
\hline AME (HPS) & $1.59 \mathrm{E}+18$ & $1.41 \mathrm{E}+18$ & 701.45 & 652.31 & 1.13 & 1.08 \\
\hline AME (LPS) & $1.34 \mathrm{E}+18$ & $7.91 \mathrm{E}+17$ & 430.98 & 110.32 & 1.70 & 3.91 \\
\hline TEN (LPS) & $1.30 \mathrm{E}+18$ & $7.56 \mathrm{E}+17$ & 80 & 113.43 & 1.73 & 0.71 \\
\hline $\mathrm{OZU}$ & $160 F+18$ & $104 \mathrm{~F}+18$ & 300 & 20687 & 163 & 145 \\
\hline
\end{tabular}

AME: Amecameca; TEN: Tenango; OZU: Ozumba; HPS: high pressure synoptic system; LPS: low pressure synoptic system.

daytime, and under high pressure synoptic systems (HPS) northerly winds (from Mexico City) dominated all morning.

In this analysis, the satellite-model (total column) ratio was compared to the observations-model ratio (in surface). Table II shows the modeled and observed (satellite and surface stations) values for the days in which satellite information was available for the area during the campaign period (February 2011). It would be expected that the ratio of the modeled and observed concentrations on surface would have the same trend as the ratios obtained from the total column data because of the prevailing winds.

For Amecameca, both ratios show the same trend and are greater than 1, suggesting that the model predicts correctly the wind direction and underestimates the total column and surface concentration. For Tenango, under LPS, the satellite-model ratio is greater than 1 , but in surface it is less than 1 , so it is likely that local effects are relevant to this station or that the model does not estimate wind direction properly. And for Ozumba, classified as a transition day by García-Yee et al. (2017), the ratios show the same trends with values greater that 1 , indicating that the model predicts wind direction correctly and underestimates the measurements.

Note that in this investigation only four points were studied, so it would be beneficial to use a greater number of comparison points (larger analysis period) and different times of the year because of the LPS and HPS predominance in different seasons. During the rainy season (from June to October), where LPS systems occurs more frequently, it would be expected that the $\mathrm{CO}$ concentration in Amecameca,
Tenango and Ozumba is more affected by southerly winds (emissions from Morelos and Puebla). On the contrary, during the warm dry season (from March to May), where the HPS are recurrent, the northerly winds might affect the $\mathrm{CO}$ concentration in these sites (emissions from Mexico City) (García-Yee et al., 2017; Molina et al., 2019).

\subsection{Statistics}

Table III shows the agreement indexes (Willmott, 1981) calculated at 10:00 LT for the RAMA stations and the measurement sites in Amecameca, Tenango and Ozumba. This statistic is a standardized measure of the degree of model prediction error compared to observations. It can vary from 0 , in which case there is no agreement, to 1 , in which case the agreement is perfect. Besides, Table IV shows the root mean square error (RMSE) for the same cases as Table III. The relative improvement (third column) is calculated

Table III. Agreement index.

\begin{tabular}{lccc}
\hline \multicolumn{3}{c}{ Agreement indexes } \\
\hline Station & Original & Scaled & $\begin{array}{c}\text { Percentage } \\
\text { difference }\end{array}$ \\
\hline Iztacalco & 0.60 & 0.62 & 3.33 \\
Merced & 0.54 & 0.59 & 9.26 \\
Santa Úrsula & 0.51 & 0.59 & 15.69 \\
Tlalnepantla & 0.53 & 0.60 & 13.21 \\
UAM-Iztapalapa & 0.53 & 0.49 & -7.55 \\
Amecameca & 0.48 & 0.56 & 16.67 \\
Tenango & 0.57 & 0.74 & 29.82 \\
Ozumba & 0.54 & 0.69 & 27.78 \\
\hline
\end{tabular}


with respect to the original so that improvement is positive: (scaled-original)/original for the agreement index and (original-scaled)/original for the RMSE-measure.

Table IV. Root mean square error $\left(\mu \mathrm{L} / \mathrm{m}^{3}\right)$

\begin{tabular}{lrrc}
\hline \multicolumn{4}{c}{ Root mean square error (RMSE) } \\
\hline Station & Original & Scaled & $\begin{array}{c}\text { Percentage } \\
\text { difference }\end{array}$ \\
\hline Iztacalco & 1531.47 & 1057.58 & 30.94 \\
Merced & 1571.34 & 1128.40 & 28.19 \\
Santa Úrsula & 1406.09 & 851.24 & 39.46 \\
Tlalnepantla & 1296.80 & 854.25 & 34.13 \\
UAM-Iztapalapa & 1360.07 & 1548.47 & -13.85 \\
Amecameca & 315.06 & 211.83 & 32.77 \\
Tenango & 417.70 & 188.13 & 54.96 \\
Ozumba & 212.59 & 106.75 & 49.79 \\
\hline
\end{tabular}

As for the agreement index, the model performance is improved (up to 29\%) in seven stations: Merced, Tlalnepantla, Amecameca, Tenango, Ozumba, Iztcacalco and Santa Úrsula. For UAM-Iztapalapa, a small decrease is observed in its value. The best agreement is obtained in Tenango using scaled emissions and the worst in Amecameca using original emissions. Regarding the RMSE, this statistic decreases for the same seven stations (up to 55\%) when the scaled emissions are used; so, according to this statistic, the model performance improve in these locations at the analysis time.

For most stations (except UAM-Iztapalapa) it is observed that the results from both statistics agree, reducing the average differences between the model results and the observations (according to RMSE) and increasing the agreement between the modeled and observed data (with respect to the agreement index). As for the UAM-Iztapalapa station, it is possible that the $\mathrm{CO}$ concentration is influenced by local factors; consequently, it is related to emissions from other regions causing the RMSE to increase and the agreement index to decrease slightly when the scaled inventories are employed.

\subsection{Time series for the RAMA and State of Mexico stations}

The time series for each RAMA station, from February 9-17, are shown in Figure 6. The green line corresponds to the model results employing original emissions, the blue line to the model results using the scaled emissions, and the yellow line to the RAMA measurements. The dotted red line indicates the time at which the comparison was made (10:00 LT).

It is observed that $\mathrm{CO}$ concentrations are reduced when the scaling factors are applied to the original emissions. For Iztacalco, Merced, Santa Úrsula and Tlalnepantla the scaled CO concentrations are always closer to observations. As for UAM- Iztapalapa, the original concentrations are closer to observations in most of the analyzed period, but some days the scaled concentrations are closer to the measurements. This could be explained by the influence of local factors related to $\mathrm{CO}$ transport from other regions.

In the case of the State of Mexico stations (Fig. 7), different patterns are observed compared to the RAMA stations. For Amecameca and Ozumba, the observations are most of the time greater than the model results using either original or scaled emissions. Regarding Tenango, the original model results are closer to the observations in the hours of high concentration from February 13-15, but in other days the difference between scaled concentrations and measurements is smaller. These results suggest that most of the days $\mathrm{CO}$ concentrations in these sites do not originate in the MCMA; therefore, the model performance would improve only in days when there is $\mathrm{CO}$ coming from the MCMA.

\subsection{Total column comparison}

Figure 8 shows the differences in molecules $\mathrm{cm}^{-2}$ between the satellite and the model results using the original (a) and scaled (b) inventories, but also in percentage employing the original (c) and scaled (d) emissions. The greatest difference between the satellite and the model is observed when the original inventories are used and decreases when the scaled inventories are employed; therefore, these results suggest that the model performance improves after scaling the carbon monoxide emissions according to the total column comparison.

\section{Conclusions}

In this paper, a method was presented and applied to compare $\mathrm{CO}$ total columns from the WRF-Chem model and the IASI instrument, based on the meth- 

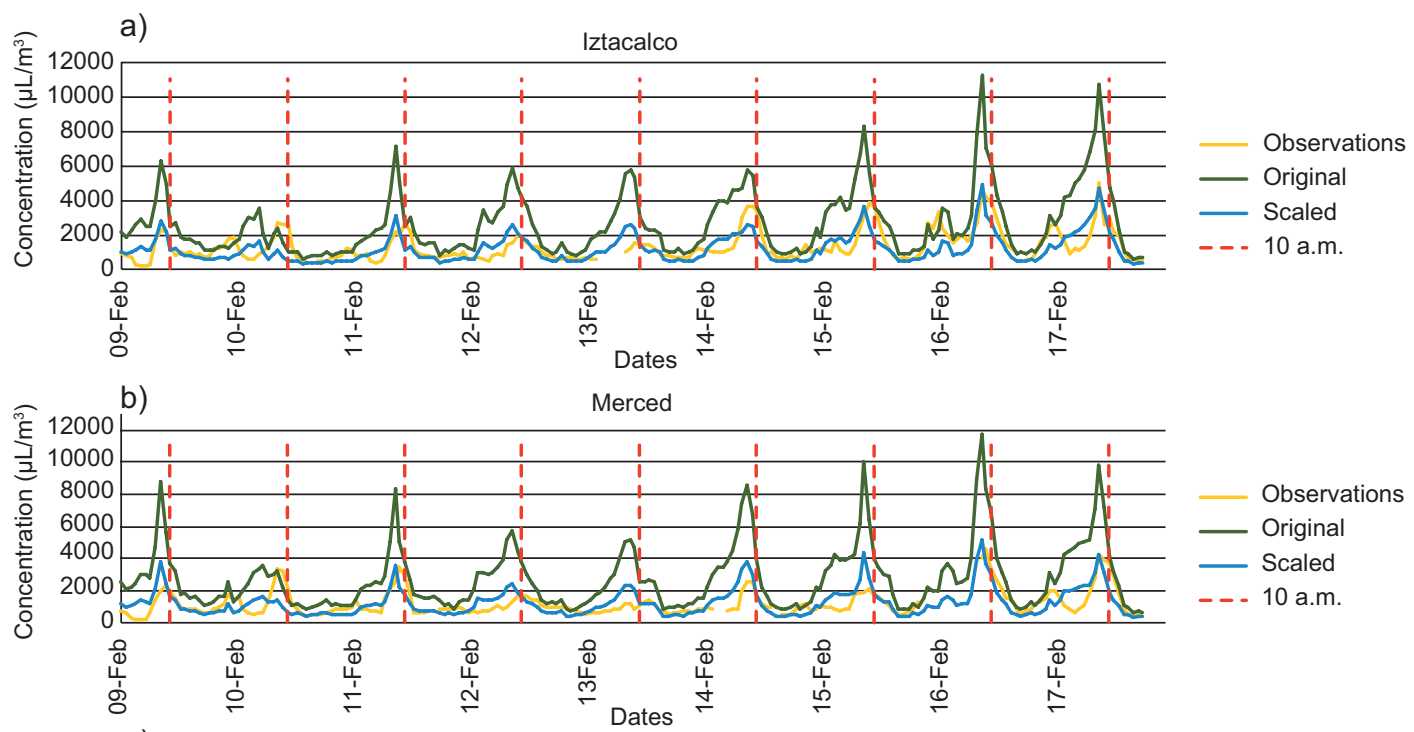

c)
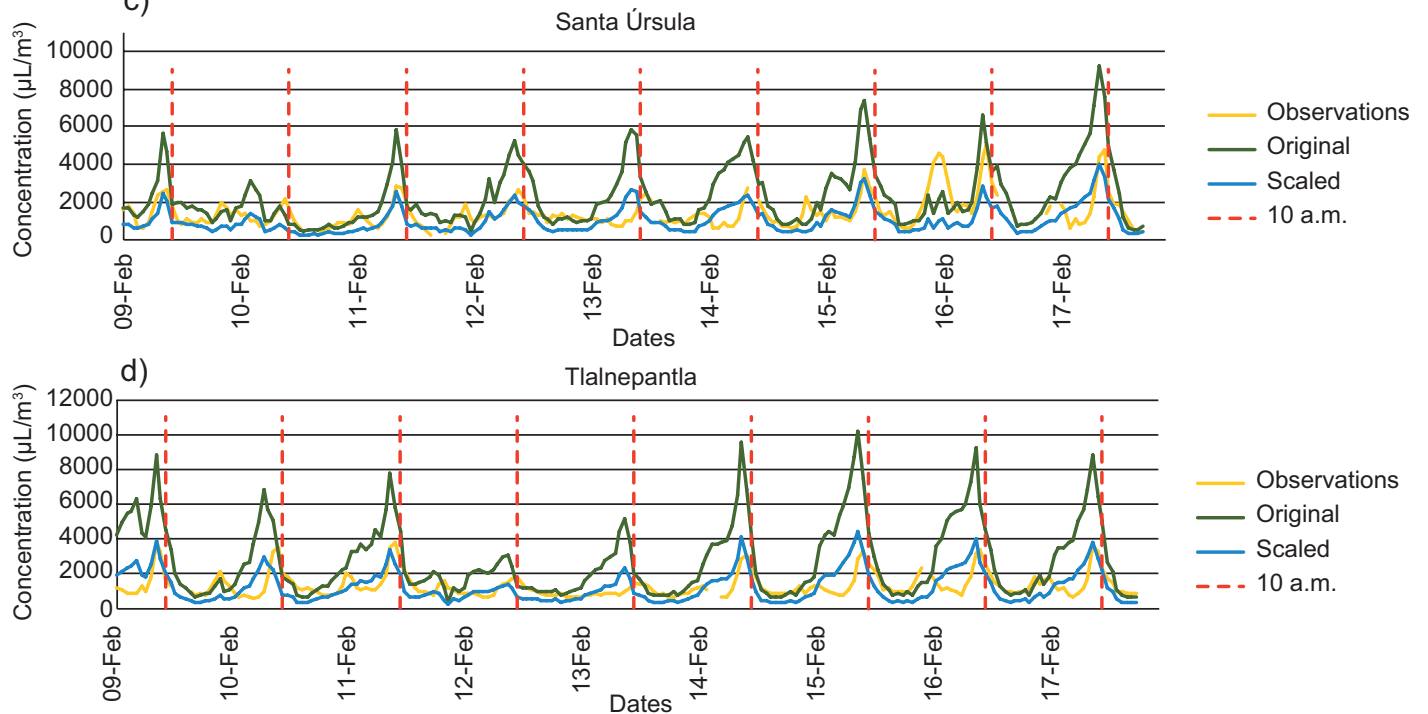

e)

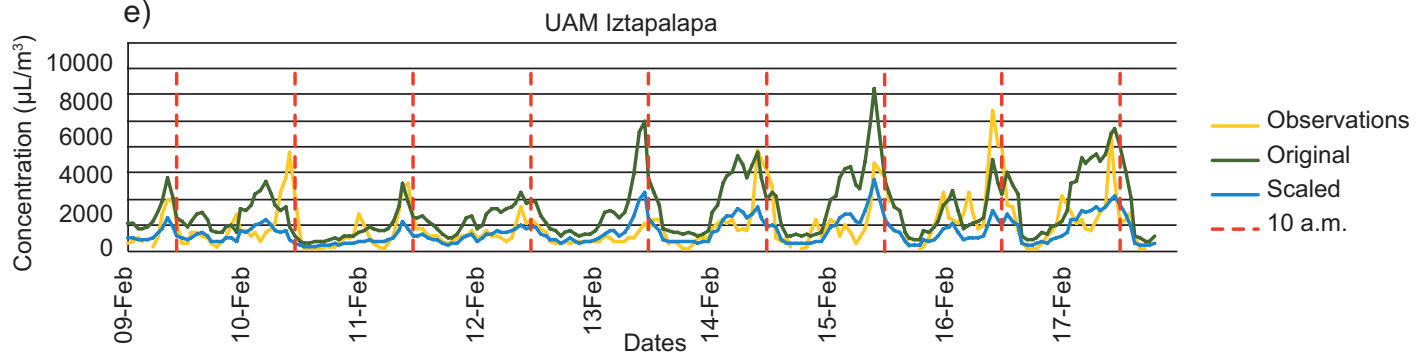

Fig. 6. Time series for the RAMA stations comparing the original and scaled modeled concentrations against measurements. 


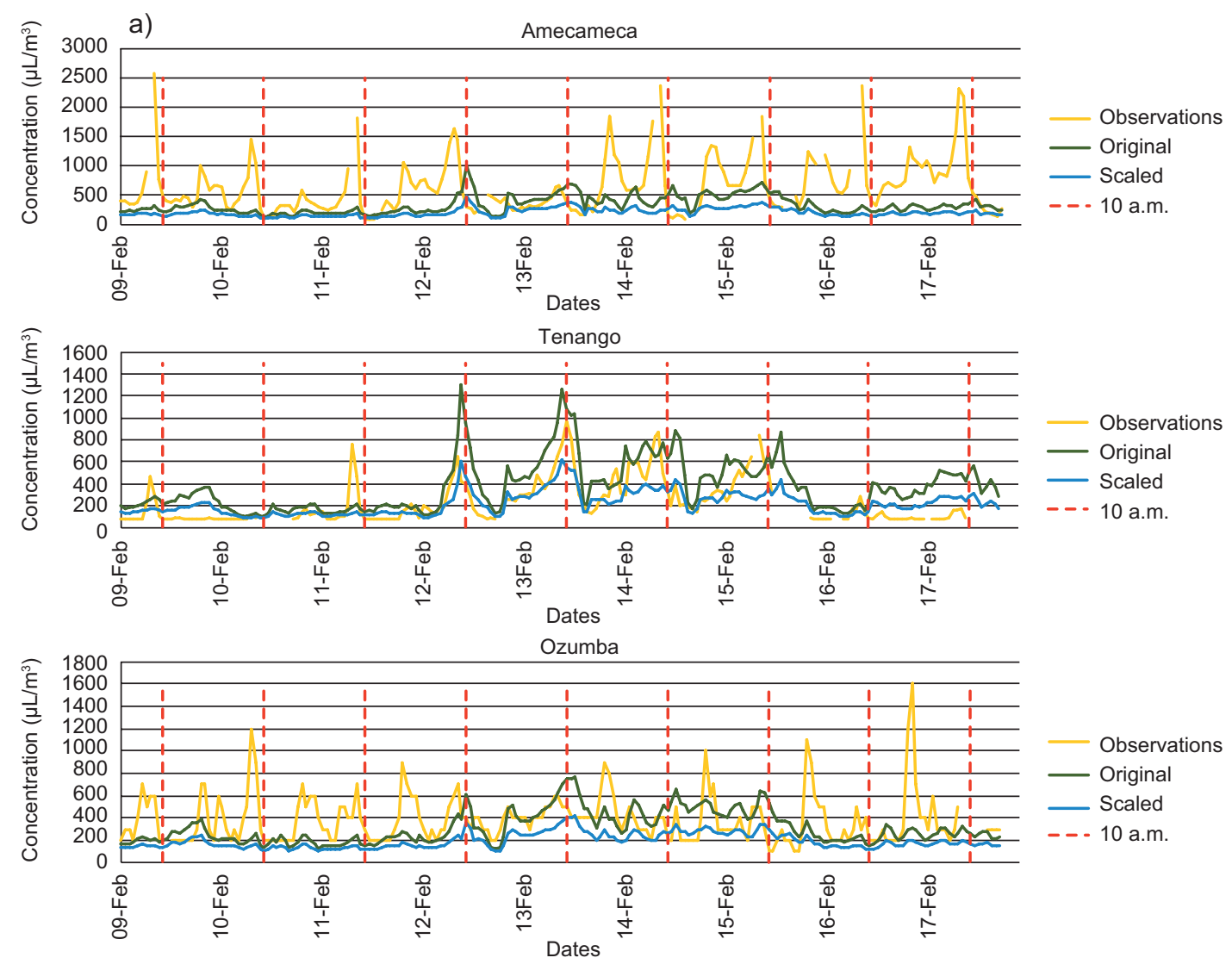

Fig. 7. Time series for the State of Mexico stations comparing the original and scaled modeled concentrations against measurements.

odology described by Rodgers and Connor (2003). From this comparison, scaling factors were estimated for different regions using the sensitivity characteristics of the instrument (averaging kernels) at the satellite crossing time over central Mexico. The results are important because if updated emissions are not available for a given period, they could be estimated by this method.

It is shown that the suggested method works for the IASI instrument at the analysis time reducing the difference between emissions in the 2008 emissions inventory and the current ones; therefore, the model performance improves in the surface level according to the estimated statistics (the agreement index increases up to $29 \%$ and the RMSE decreases up to $55 \%$ ) and the time series (in which the scaled model concentrations approach to the observations in many cases).

Even though the concentration reported by the model is a cell of $3 \times 3 \mathrm{~km}$, in which several stations can exist, the model performance improves in most of the sites suggesting these types of data can be compared. The analysis may be done in higher resolution depending on the available computing resources.

It is recommended to perform the analysis over a larger period, since this would provide a greater number of comparison points; also, to include other satellite instruments such as the Tropospheric Monitoring Instrument (TROPOMI) and Measurement of Pollution in the Troposphere (MOPITT), because this would allow to analyze additional times other than 10:00 LT as well as the vertical dispersion scheme of the model, which may contribute to the attainment of different modeled vertical profiles. Since the scaling factors must always be interpreted relative to the inventory employed, in future works we suggest using other emission inventories as starting points, and then comparing the results. Since the method may be used in other modeled regions and time periods 

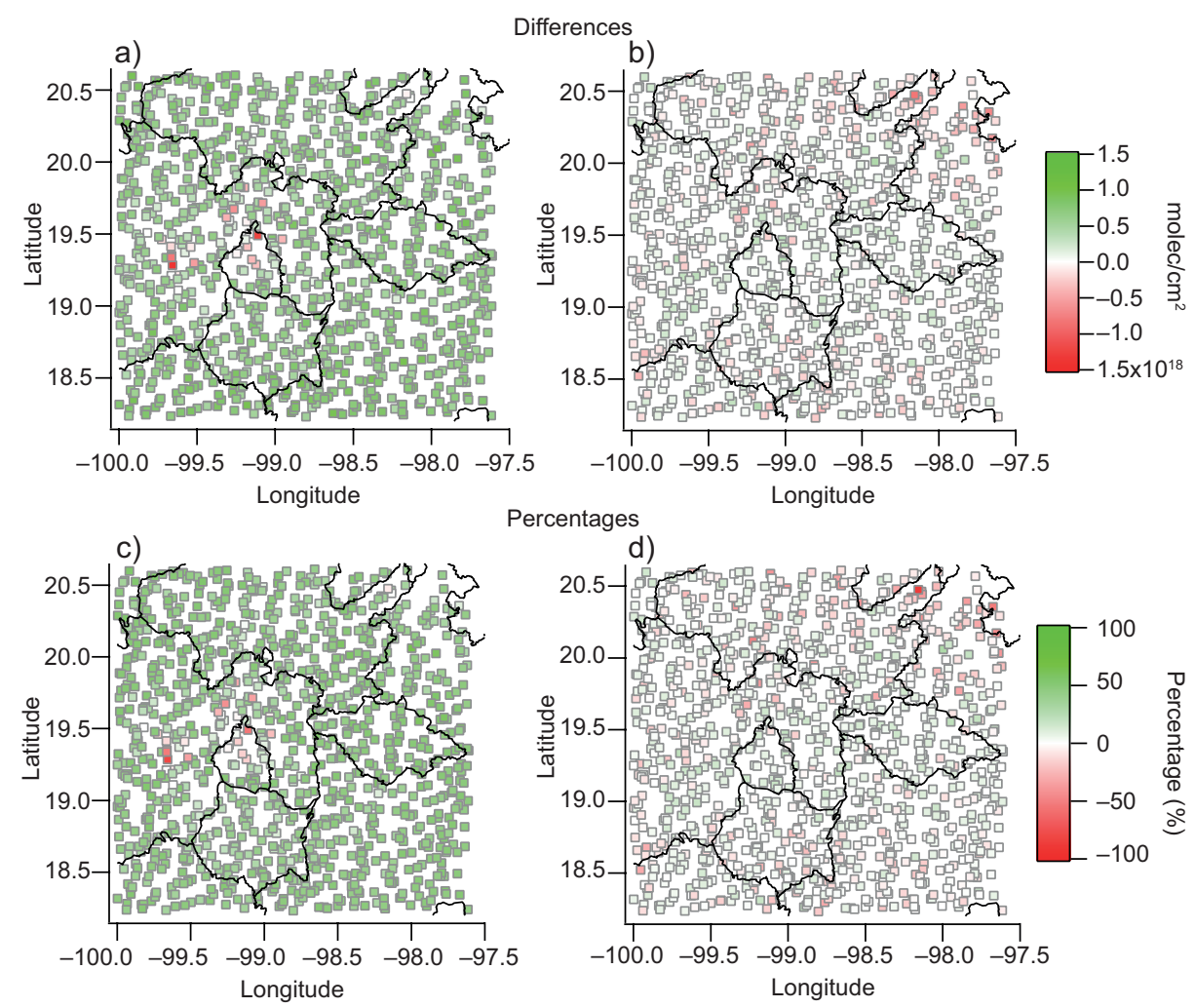

Fig. 8. Satellite minus (a) original and (b) scaled model (in molecules $\mathrm{cm}^{-2}$ ). Difference in column units (molecules $\mathrm{cm}^{-2}$ ) and percentage using original (a, c) and scaled (b, d) emissions.

provided there are satellite measurements, it can be considered as an important tool for investigating trends and comparing different megacities.

\section{Acknowledgments}

IASI is a joint mission of Eumetsat and the Centre National d'Etudes Spatiales (CNES, France). The authors acknowledge the Aeris data infrastructure (http://iasi.aeris-data.fr/CO/) for providing access to the IASI CO data used in this study. The authors also gratefully acknowledge the computing time granted by LANCAD and CONACYT on the supercomputer Miztli at DGTIC UNAM and by the supercomputing area at the Atmospheric Sciences Center (CCA), UNAM. We also thank the support and work of Bertha Eugenia Mar Morales in the generation of the high-quality images included in this article. CONACYT is acknowledged for founding this study through a student fellowship, and UNAM DGAPA-PAPIIT IN111418 is also acknowledged for its support in computational infrastructure. We thank Alejandro Bezanilla Morlot for his support in the use of the computational infrastructure.

\section{References}

Bauduin S, Clarisse L, Theunissen M, George M, Hurtmans D, Clerbaux C and Coheur P-F. 2016. IASI's sensitivity to near-surface carbon monoxide (CO): Theoretical analyses and retrievals on test cases. Journal of Quantitative Spectroscopy and Radiative Transfer 189: 428-440. https://doi.org/10.1016/j.jqsrt.2016.12.022

Clerbaux C, George M, Turquety S, Walker KA, Barret B, Bernath P, Boone C, Borsdorff T, Cammas JP, Catoire V, Coffey M, Coheur P-F, Deeter M, De Mazière M, Drummond J, Duchatelet P, Dupuy E, de Zafra R, Eddounia F, Edwards DP, Emmons L, Funke B, Gille J, 
Griffith DWT, Hannigan J, Hase F, Höpfner M, Jones N, Kagawa A, Kasai Y, Kramer I, Le Flochmoën E, Livesey NJ, López-Puertas M, Luo M, Mahieu E, Murtagh D, Nédélec P, Pazmino A, Pumphrey H, Ricaud P, Rinsland CP, Robert C, Schneider M, Senten C, Stiller G, Strandberg A, Strong K, Sussmann R, Thouret V, Urban J and Wiacek A. 2008a. CO measurements from the ACE-FTS satellite instrument: data analysis and validation using ground-based, airborne and spaceborne observations. Atmospheric Chemistry and Physics 8: 2569-2594. https://doi.org/10.5194/ acp-8-2569-2008

Clerbaux C, Edwards DP, Deeter M, Emmons L, Lamarque J-F, Tie X X, Massie ST and Gille J. 2008b. Carbon monoxide pollution from cities and urban areas observed by the Terra/MOPITT mission. Geophysical Research Letters 35: L03817. https://doi. org/10.1029/2007GL032300

Clerbaux C, Boynard A, Clarisse L, George M, Hadji-Lazaro J, Herbin H, Hurtmans D, Pommier M, Razavi A, Turquety S, Wespes C and Coheur P-F. 2009. Monitoring of atmospheric composition using the thermal infrared IASI/MetOp sounder. Atmospheric Chemistry and Physics 9: 6041-6054. https://doi. org/10.5194/acp-9-6041-2009

De Foy B, Lei W, Zavala M, Volkamer R, Samuelsson J, Mellqvist J, Galle B, Martínez A-P, Grutter M, Retama A and Molina LT. 2007. Modelling constraints on the emission inventory and on vertical dispersion for $\mathrm{CO}$ and $\mathrm{SO}_{2}$ in the Mexico City Metropolitan Area using Solar FTIR and zenith sky UV spectroscopy. Atmospheric Chemistry and Physics 7: 781-801. https://doi. org/10.5194/acp-7-781-2007

De Wachter E, Barret B, Le Flochmoën E, Pavelin E, Matricardi M, Clerbaux C, Hadji-Lazaro J, George M, Hurtmans D, Coheur P-F, Nedelec P and Cammas JP. 2012. Retrieval of MetOp-A/IASI CO profiles and validation with MOZAIC data. Atmospheric Measurements Techniques 5: 2843-2857. https://doi. org/10.5194/amt-5-2843-2012

Fagbeja MA, Hill JL, Chatterton TJ and Longhurst JWS. 2015. A GIS-based assessment of the suitability of SCIAMACHY satellite sensor measurements for estimating reliable $\mathrm{CO}$ concentrations in a low-latitude climate. Environmental Monitoring and Assessment 187: 4227. https://doi.org/10.1007/s10661-014-4227-2

Fast JD, Gustafson WI Jr, Easter RC, Zaveri RA, Barnard JC, Chapman EG, Grell GA and Peckham SE. 2006.
Evolution of ozone, particulates, and aerosol direct radiative forcing in the vicinity of Houston using a fully coupled meteorology-chemistry-aerosol model. Journal of Geophysical Research 111: D21305. https:// doi.org/10.1029/2005JD006721

Fortems-Cheiney A, Chevallier F, Pison I, Bousquet P, Carouge C, Clerbaux C, Coheur P-F, George M, Hurtmans D and Szopa S. 2009. On the capability of IASI measurements to inform about CO surface emissions. Atmospheric Chemistry and Physics 9: 8735-8743. https://doi.org/10.5194/acp-9-8735-2009

Funke B, López-Puertas M, Bermejo-Pantaleón D, von Clarmann T, Stiller GP, Höpfner M, Grabowski U and Kaufmann M. 2007. Analysis of nonlocal thermodynamic equilibrium $\mathrm{CO} 4.7 \mathrm{~mm}$ fundamental, isotopic, and hot band emissions measured by the Michelson Interferometer for Passive Atmospheric Sounding on Envisat. Journal of Geophysical Research 112: D11305. https://doi.org/10.1029/2006JD007933

García-Reynoso JA, Mar-Morales BE and Ruiz-Suárez LG. 2018. Modelo de distribución espacial, temporal y de especiación del inventario de emisiones de México (año base 2008) para su uso en modelización de calidad del aire (DiETE). Revista Internacional de Contaminación Ambiental 34 (4): 635-649. https://doi. org/10.20937/RICA.2018.34.04.07

García-Yee JS, Torres-Jardón R, Barrera-Huertas H, Castro T, Peralta O, García M, Gutiérrez W, Robles M, Torres-Jaramillo JA, Ortínez Álvarez A and Ruiz-Suárez LG. 2017. Characterization of $\mathrm{NO}_{\mathrm{x}}-\mathrm{O}_{\mathrm{x}}$ relationships during daytime interchange of air masses over a mountain pass in the Mexico City megalopolis. Atmospheric Environment 177: 100-110. https://doi.org/10.1016/j. atmosenv.2017.11.017

George M, Clerbaux C, Hurtmans D, Turquety S, Coheur P-F, Pommier M, Hadji-Lazaro J, Edwards DP, Worden H, Luo M, Rinsland C and McMillan W. 2009. Carbon monoxide distributions from the IASI/METOP mission: Evaluation with other spaceborne remote sensors. Atmospheric Chemistry and Physics 9: 8317-8330. https://doi.org/10.5194/acp9-8317-2009

Grell GA. 1993. Prognostic evaluation of assumptions used by cumulus parameterizations. Monthly Weather Review 121: 764-787. https://doi.org/10.1175/1520-0 493(1993)121<0764:PEOAUB > 2.0.CO;2

Grell GA and Dévényi D. 2002. A generalized approach to parameterizing convection combining ensemble and 
data assimilation techniques. Geophysical Research Letters 29 (14). https://doi.org/10.1029/2002GL015311 Grell GA, Peckham SE, Schmitz R, McKeen SA, Frost G, Skamarock WC and Eder B. 2005. Fully coupled "online" chemistry within the WRF model. Atmospheric Environment 39: 6957-6975. https://doi.org/10.1016/j. atmosenv.2005.04.027

Hilton F, Armante R, August T, Barnet C, Bouchard A, Camy-Peyret C, Capelle V, Clarisse L, Clerbaux C, Coheur P-F, Collard A, Crevoisier C, Dufour G, Edwards D, Faijan F, Fourrié N, Gambacorta A, Goldberg M, Guidard V, Hurtmans D, Illingworth S, Jacquinet-Husson N, Kerzenmacher T, Klaes D, Lavanant L, Masiello G, Matricardi M, McNally T, Newman S, Pavelin E, Payan S, Péquignot E, Peyridieu S, Phulpin T, Remedios J, Schlüssel P, Serio C, Strow L, Stubenrauch C, Taylor J, Tobin D, Wolf W and Zhou, D. 2012. Hyperspectral earth observation from IASI: Five years of accomplishments. Bulletin of the American Meteorological Society 93: 347-370. https://doi.org/10.1175/BAMS-D-11-00027.1

Hurtmans D, Coheur P-F, Wespes C, Clarisse L, Scharf O, Clerbaux C, Hadji-Lazaro J, George M and Turquety S. 2012. FORLI radiative transfer and retrieval code for IASI. Journal of Quantitative Spectroscopy and Radiative Transfer 113: 1391-1408. https://doi. org/10.1016/j.jqsrt.2012.02.036

Kerzenmacher T, Dils B, Kumps N, Blumenstock T, Clerbaux CC, Coheur P-F, Demoulin P, García O, George M, Griffith DWT, Hase F, Hadji-Lazaro J, Hurtmans D, Jones N, Mahieu E, Notholt J, Paton-Walsh C, Raffalski U, Ridder T, Schneider M, Servais C and de Mazière M. 2012. Validation of IASI FORLI carbon monoxide retrievals using FTIR data from NDACC. Atmospheric Measurements Techniques 5: 2751-2761. https://doi.org/10.5194/amt-5-2751-2012

Klonecki A, Pommier M, Clerbaux C, Ancellet G, Cammas J-P, Coheur P-F, Cozic A, Diskin GS, Hadji-Lazaro J, Hauglustaine DA, Hurtmans D, Khattatov B, Lamarque J-F, Law KS, Nedelec P, Paris J-D, Podolske JR, Prunet P, Schlager H, Szopa S and Turquety S. 2012. Assimilation of IASI satellite CO fields into a global chemistry transport model for validation against aircraft measurements. Atmospheric Chemistry and Physics 12: 4493-4512. https://doi.org/10.5194/acp12-4493-2012

Kopacz M, Jacob DJ, Henze DK, Heald CL, Streets DG and Zhang Q. 2009. Comparison of adjoint and ana- lytical Bayesian inversion methods for constraining Asian sources of carbon monoxide using satellite (MOPITT) measurements of CO columns. Journal of Geophysical Research 114: D04305. https://doi. org/10.1029/2007JD009264

Liu J, Drummond JR, Li Q, Gille JC and Ziskin DC. 2005. Satellite mapping of $\mathrm{CO}$ emission from forest fires in Northwest America using MOPITT measurements. Remote Sensing of Environment 95: 502-516. https:// doi.org/10.1016/j.rse.2005.01.009

Luo M, Rinsland CP, Rodgers CD, Logan JA, Worden H, Kulawik S, Eldering A, Goldman A, Shepard M W, Gunson M and Lampel M. 2007. Comparison of carbon monoxide measurements by TES and MOPITT: Influence of a priori data and instrument characteristics on nadir atmospheric species retrievals. Journal of Geophysical Research 112: D09303. https://doi. org/10.1029/2006JD007663

Marey HS, Hashisho Z, Fu L and Gille J. 2015. Spatial and temporal variation in $\mathrm{CO}$ over Alberta using measurements from satellites, aircraft, and ground stations. Atmospheric Chemistry and Physics 15: 3893-3908. https://doi.org/10.5194/acp-15-3893-2015

Matsui T, Zhang SQ, Tao W-K, Lang S, Ichoku C and Peters-Lidard C. 2018. Impact of radiation frequency, precipitation radiative forcing, and radiation column aggregation on convection-permitting West African monsoon simulations. Climate Dynamics 55: 193-213. https://doi.org/10.1007/s00382-018-4187-2

Mlawer EJ, Taubman SJ, Brown PD, Iacono MJ and Clough SA. 1997. Radiative transfer for inhomogeneous atmospheres: RRTM, a validated correlated-k model for the longwave. Journal of Geophysical Research 102: 16663-16682. https://doi.org/10.1029/ 97JD00237

Molina LT, Velasco E, Retama A and Zavala M. 2019. Experience from Integrated Air Quality Management in the Mexico City Metropolitan Area and Singapore. Atmosphere 10: 512. https://doi.org/10.3390/ atmos 10090512

Rakitin VS, Shtabkin YA, Elansky NF, Pankratova NV, Skorokhod AI, Grechko EI and Safronov AN. 2015. Comparison results of satellite and ground-based spectroscopic measurements of $\mathrm{CO}, \mathrm{CH}_{4}$, and $\mathrm{CO}_{2}$ total contents. Atmospheric and Oceanic Optics 28: 533-542. https://doi.org/10.1134/S1024856015060135

Rakitin VS, Elansky NF, Pankratova NV, Skorokhod AI, Dzhola AV, Shtabkin YA, Wang P, Wang G, 
Vasilieva AV, Makarova MV and Grechko EI. 2017. Study of trends of total $\mathrm{CO}$ and $\mathrm{CH}_{4}$ contents over Eurasia through analysis of ground-based and satellite spectroscopic measurements. Atmospheric and Oceanic Optics 30: 517-526. https://doi.org/10.1134/ S1024856017060112

Rinsland CP, Luo M, Logan JA, Beer R, Worden H, Kulawik SS, Rider D, Osterman G, Gunson M, Eldering A, Goldman A, Shepard M, Shepard AC, Clough SA, Rodgers C, Lampel M and Chiou L. 2006. Nadir measurements of carbon monoxide distributions by the Tropospheric Emission Spectrometer instrument onboard the Aura Spacecraft: Overview of analysis approach and examples of initial results. Geophysical Research Letters 33: L22806. https://doi. org/10.1029/2006GL027000

Rodgers CD. 2000. Inverse methods for atmospheric sounding. Theory and practice. Series on Atmospheric, Oceanic and Planetary Physics, vol. 2. World Scientific Publishing. https://doi.org/10.1142/3171

Rodgers CD and Connor BJ. 2003. Intercomparison of remote sounding instruments. Journal of Geophysical Research 108: 4116. https://doi.org/10.1029/ 2002JD002299

Song-You H, Dudhia J and Chen S-H. 2004. A revised approach to ice microphysical processes for the bulk parameterization of clouds and precipitation. Monthly Weather Review 132: 103 120. https://doi.org/10.1175/1520-0493(2004)132< 0103:ARATIM>2.0.CO;2

Song-You H, Noh Y and Dudhia J. 2006. A new vertical diffusion package with an explicit treatment of entrainment processes. Monthly Weather Review 134: 2318-2341. https://doi.org/10.1175/MWR3199.1
Stremme W, Grutter M, Rivera C, Bezanilla A, García AR, Ortega I, George M, Clerbaux C, Coheur P-F, Hurtmans D, Hannigan JW and Coffey MT. 2013. Top-down estimation of carbon monoxide emissions from the Mexico Megacity based on FTIR measurements from ground and space. Atmospheric Chemistry and Physics 13: 1357-1376. https://doi.org/10.5194/acp-13-1357-2013.

Tanimoto H, Sato K, Butler T, Lawrence MG, Fisher JA, Kopacz M, Yantosca RM, Kanaya Y, Kato S, Okuda T, Tanaka S and Zeng J. 2009. Exploring CO pollution episodes observed at Rishiri Island by chemical weather simulations and AIRS satellite measurements: longrange transport of burning plumes and implications for emissions inventories. Tellus Series B-Chemical and Physical Meteorology 61: 394-407. https://doi. org/10.1111/j.1600-0889.2008.00407.x

Turquety S, Clerbaux C, Law K, Coheur P-F, Cozic A, Szopa S, Hauglustaine DA, Hadji-Lazaro J, Gloudemans AMS, Schrijver H, Boone CD, Bernath PF and Edwards DP. 2008. CO emission and export from Asia: An analysis combining complementary satellite measurements (MOPITT, SCIAMACHY and ACE-FTS) with global modeling. Atmospheric Chemistry and Phyisics 8: 51875204. https://doi.org/10.5194/acp-8-5187-2008

Turquety S, Hurtmans D, Hadji-Lazaro J, Coheur P-F, Clerbaux C, Josset D and Tsamalis C. 2009. Tracking the emission and transport of pollution from wildfires using the IASI CO retrievals: Analysis of the summer 2007 Greek fires. Atmospheric Chemistry and Phyisics 9: 4897-4913. https://doi.org/10.5194/ acp-9-4897-2009

Willmott CJ. 1981. On the validation of models. Physical Geography 2: 184-194. https://doi.org/10.1080/02723 646.1981 .10642213 